\title{
Maternal mortality in a tertiary care centre in North India: a retrospective study
}

\author{
Prachi Sarin Sethi $^{1 *}$, Sujata Sharma ${ }^{1}$, Indu Chawla ${ }^{2}$
}

\begin{abstract}
${ }^{1}$ Department of Obstetrics and Gynecology, Government Medical College, Amritsar, Punjab, India
${ }^{2}$ Department of Obstetrics and Gynecology, PGIMER, Dr. R.M.L Hospital, New Delhi, India
\end{abstract}

Received: 09 October 2017

Accepted: 04 November 2017

\section{*Correspondence:}

Dr. Prachi Sarin Sethi,

E-mail: prachi.sarin@gmail.com

Copyright: (c) the author(s), publisher and licensee Medip Academy. This is an open-access article distributed under the terms of the Creative Commons Attribution Non-Commercial License, which permits unrestricted non-commercial use, distribution, and reproduction in any medium, provided the original work is properly cited.

\begin{abstract}
Background: The World Health Organization (WHO) estimates that, of 536,000 maternal deaths occurring globally each year, 136,000 take places in India. Maternal death has serious implications to the family, the society and the nation. It deprives the surviving infant of mother's care. This study was done to assess maternal mortality in a tertiary care centre in north India where large numbers of patients are referred from the peripheral centers and the rural parts. This study was done to assess the causes of maternal mortality and suggest remedial measures to reduce the same. Objective of present study was to assess the causes of maternal death over a period of one year at G.M.C Amritsar, India.

Methods: A retrospective hospital based study of 22 maternal deaths over a period of 1 year from June 2012 to June 2013. The information regarding demographic profile and reproductive parameters were collected and results were analyzed.

Results: Over the study period, there were 22 deaths and 7272 live births (Majority were referral from other districts all over Punjab). Most common direct cause of maternal mortality was haemorrhage and anemia was the most common indirect cause. Most maternal deaths were seen in patients from rural areas, unbooked, illiterate patients and patients from low socioeconomic status.

Conclusions: Proper health education should be given to the women; early registration of antenatal cases should be done which allows for rapid diagnosis and treatment of high risk cases. Also constructing a well equipped health care facility with trained staff and prompt transport facilities for early referral can bring down the maternal mortality rate in our country.
\end{abstract}

Keywords: Causes of maternal death, Maternal mortality, MMR

\section{INTRODUCTION}

Maternal mortality is defined as the death of any woman while being pregnant or within 42 completed days of termination of pregnancy, irrespective of the duration or site of pregnancy, from any cause related to or aggravated by pregnancy, but not from accidental or incidental causes. Maternal mortality is defined, as maternal death rate per 1,00,000 live births. ${ }^{1}$ The World Health Organization (WHO) estimates that, of 536,000 maternal deaths occurring globally each year, 136,000 take place in India. Estimates of the global burden of disease for 1990 also showed that India contributed $25 \%$ to disability-adjusted life-years lost due to maternal conditions alone. ${ }^{2}$

Each year in India- 26 million women experience pregnancy and 24 million have a live birth. Of these 57,000 maternal deaths the major direct cause of maternal death is Haemorrhage. MMR for India was 301 per 
100,000 live births by Sample Registration Survey (SRS) 2003 estimate and came down to 167 by SRS survey 2013 estimate. $^{3}$

Maternal death has serious implications to the family, the society and the nation. It deprives the surviving infant of mother's care. Maternal mortality is an indicator of the quality of obstetric care in a community, directly reflecting the utilization of healthcare services available. ${ }^{4}$

This study was done to assess maternal mortality in a tertiary care centre in north India where large numbers of patients are referred from the peripheral centers and the rural parts. This study was done to assess the causes of maternal mortality and suggest remedial measures to reduce the same.

\section{METHODS}

A retrospective hospital based study was carried out in the Obstetrics and Gynecology Department in Bebe Nanki Maternal and child care centre in G.M.C. Amritsar over a period of 1 year from June 2012- June 2013. A total 22 maternal deaths were analyzed with emphasis on socio-demographic profile of the patient, parity, cause of death, time interval from admission to death, and trimester of pregnancy at the time of death.

\section{Inclusion criteria}

The study included all maternal deaths occurring during pregnancy and within 42 days of delivery, ectopic pregnancies, septic abortions, molar pregnancies.

\section{Exclusion criteria}

The study excluded all maternal deaths occurring after 42 days of termination of pregnancy.

\section{RESULTS}

In the present study it was observed that out of 22 deaths, $13(59 \%)$ maternal deaths occurred in the age group of $19-24$ years, followed by 3 deaths $(13.6 \%)$ in $<19$ years and 25-29 years (Table 1). Majority i.e. 12 deaths $(55 \%)$ took place in the multigravida, followed by $9(41 \%)$ in primigravida and only 1 in grand multi (Table 1$)$. It was observed that only 4 patients $(18 \%)$ were booked cases, wherein $18(82 \%)$ were unbooked cases (Table 1$)$. In the present study, 20 patients $(90 \%)$ resided in rural area and only $2(10 \%)$ of them resided in urban area (Table 1$)$. It was observed that $13(60 \%)$ patients were illiterate and 5 $(22 \%)$ and $4(18 \%)$ patients had primary and middle education respectively (Table 1$)$. Only 5 (23\%) patients belonged to upper lower class and rest $17(77 \%)$ belonged to the lower class (Table 1). In the present study, $10(45 \%)$ patients were landless labourers, whereas $8(36 \%)$ were cultivators, followed by $3(13.6 \%)$ housewives and only 1 patient was in service (Table 1 ).
Table 1: Sociodemographic parameters.

\begin{tabular}{|c|c|c|}
\hline Parameters & $\begin{array}{l}\text { Maternal } \\
\text { deaths }(n=22)\end{array}$ & Percentage \\
\hline \multicolumn{3}{|l|}{ Age } \\
\hline$<19$ years & 3 & 13.6 \\
\hline $19-24$ years & 13 & 59 \\
\hline $25-29$ years & 3 & 13.6 \\
\hline $30-34$ years & 1 & 4.5 \\
\hline$>35$ years & 2 & 9.09 \\
\hline \multicolumn{3}{|l|}{ Parity } \\
\hline Primigravida & 9 & 41 \\
\hline Multigravida & 12 & 55 \\
\hline Grand multigravida & 1 & 4 \\
\hline \multicolumn{3}{|c|}{ Antenatal registration } \\
\hline Booked & 4 & 18 \\
\hline Unbooked & 18 & 82 \\
\hline \multicolumn{3}{|l|}{ Residence } \\
\hline Rural & 20 & 90 \\
\hline Urban & 2 & 10 \\
\hline \multicolumn{3}{|l|}{ Education } \\
\hline Illiterate & 13 & 60 \\
\hline Primary education & 5 & 22 \\
\hline Middle & 4 & 18 \\
\hline \multicolumn{3}{|c|}{ Socioeconomic status } \\
\hline Upper lower class & 5 & 23 \\
\hline Lower class & 17 & 77 \\
\hline \multicolumn{3}{|l|}{ Occupation } \\
\hline Landless labourers & 10 & 45 \\
\hline Cultivators & 8 & 36 \\
\hline Housewives & 3 & 13.6 \\
\hline Service & 1 & 4.5 \\
\hline
\end{tabular}

In the present study most, common direct cause of maternal death was haemorrhage, in $7(31.8 \%)$ patients. 3 maternal deaths $(13.6 \%)$ each were noted due to eclampsia and sepsis. 1 maternal death due to embolism. Among the indirect causes, leading cause of maternal death was anaemia in 3 patients (13.6\%), followed by 2 $(9.09 \%)$ due to hepatitis and 2 due to heart disease. Only 1 maternal death $(4.5 \%)$ occurred due to encephalitis (Table 2).

Table 2: Causes of maternal death.

\begin{tabular}{|lll|}
\hline $\begin{array}{l}\text { Causes of } \\
\text { maternal death }\end{array}$ & $\begin{array}{l}\text { Maternal } \\
\text { deaths }(\mathbf{n = 2 2})\end{array}$ & Percentage \\
\hline Haemorrhage & 7 & 31.8 \\
\hline Eclampsia & 3 & 13.6 \\
\hline Sepsis & 3 & 13.6 \\
\hline Embolism & 1 & 4.5 \\
\hline Anaemia & 3 & 13.6 \\
\hline Hepatitis & 2 & 9.09 \\
\hline Heart disease & 2 & 9.09 \\
\hline Encephalitis & 1 & 4.5 \\
\hline
\end{tabular}

Table 3 shows that 6 out of 22 deaths (27\%) took place within 1 hour of admission, 4 maternal deaths occurred within 7-12 hours and 4 occurred within $25-48$ hours. 3 
(14\%) deaths occurred within 13-24 hours and 3 occurred $>48$ hours. 2 deaths occurred within 1-6 hours of admission (Table 3).

Table 3: Admission-death interval.

\begin{tabular}{|lll|}
\hline $\begin{array}{l}\text { Admission-death } \\
\text { interval }\end{array}$ & $\begin{array}{l}\text { Maternal } \\
\text { deaths }(\mathrm{n}=22)\end{array}$ & Percentage \\
\hline Within 1 hour & 6 & 27 \\
\hline 1-6 hours & 2 & 9 \\
\hline 7-12 hours & 4 & 18 \\
\hline 13-24 hours & 3 & 14 \\
\hline 25-48 hours & 4 & 18 \\
\hline$>48$ hours & 3 & 14 \\
\hline
\end{tabular}

\section{DISCUSSION}

Maternal mortality is an index of reproductive health of the society. High incidence of maternal deaths reflects poor quality of maternal services, late referral and low socioeconomic status of the community.

In the present study, there were 22 maternal deaths amongst 7272 deliveries. G.M.C. Amritsar is teaching institution and a tertiary care centre, gets complicated cases from rural areas all over Punjab. Moribund cases get referred from periphery and this is the cause of such high maternal mortality here.

It was observed that $59 \%$ (22 deaths) of maternal deaths were in the age group 19-24 years and 13.6\% (3 deaths) were in $<19$ years (Table 1 ). This is due to the custom of early marriage in rural areas of Punjab. This was in comparison to study done by Kaur et al which revealed that $51.8 \%$ of deaths were in $20-30$ years, $19.6 \%$ in teenage pregnancies and $23.3 \%$ in $>30$ years. ${ }^{5}$ Taneja $\mathrm{P}$ also observed that $78 \%$ of deaths in 20-30 years. ${ }^{6}$ Similarly Bangal et al in their study observed that $55.27 \%$ maternal deaths were in the age group of 19-24 years. ${ }^{7}$

Majority i.e. $55 \%$ of the maternal deaths were in the multigravida (Table 1). This shows that too many pregnancies and short interconception period adversely affects the health and social status of the women. Sikdar et al revealed that $(25.5 \%)$ deaths in primigravidas and $(74.5 \%)$ in multigravidas. ${ }^{8}$ Also Agarwal et al reported that high deaths among multiparas (43\%) than the primiparas $(25 \%) .{ }^{9}$ Thomas et al showed that primigravida contributing to $29.2 \%$ and multigravida $50.8 \%$ of deaths. ${ }^{10}$ In a study done by Bangal et al, out of the 38 deaths, $16(42.10 \%)$ deaths were among

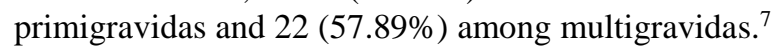

In the present study 4 patients $(18 \%)$ were booked cases, wherein $18(82 \%)$ were unbooked cases (Table 1). This shows that regular antenatal checkups decrease the maternal mortality rate. In studies done by Kaur et al, Pal A et al and Verma A et al more than $80 \%$ maternal deaths were unbooked. ${ }^{5,11,12}$
It was observed that out of 22 maternal deaths, 20 mothers resided in rural area (Table 1). In study done by Padmanabhan $\mathrm{P}$ et al (44\% maternal deaths belonged to urban slum areas)..$^{13}$ this was comparable to the study done by $\mathrm{Pal} \mathrm{A}$ et al $(40 \%) .{ }^{11}$

In the present study, 60\% (13) mothers were illiterate (Table 1). This was in concordance to study done by Bangal et al where majority $(57.90 \%)$ were illiterate and only $(21.05 \%)$ had studied up to primary and secondary level. $^{7}$

Majority of the mothers belong to upper lower class (23\%) and $45 \%$ were landless labourers, $36 \%$ were cultivators (Table 1).

It is observed that educated women go in for late marriages and therefore late child bearing. They have better knowledge about family planning. Illiteracy, lack of knowledge about health facilities leads to poor health seeking behavior and inaccessibility of health care facilities in rural areas and urban slums which is responsible for high maternal mortality.

It was observed that the most common direct cause of maternal death was haemorrhage $(31.8 \%), 3$ each (13.6\%) of maternal deaths were due to eclampsia and sepsis. Embolism contributed to $1 \%$ of maternal deaths. The most common indirect cause of maternal death was anaemia (3 maternal deaths), 2 deaths each were due to hepatitis and heart disease. One death was due to encephalitis (Table 2). In studies by Verma $A$ et al $(21.50 \%)$, hemorrhage was the main cause of maternal deaths. ${ }^{12}$ In a study done by Bangal et al both direct and indirect causes contributed to $(50.00 \%)$ of maternal death. Most common direct cause of maternal death was hemorrhage $(21.05 \%)$, followed by eclampsia and pulmonary embolism (10.52\%) and sepsis (7.89\%) (Puerperal sepsis, ante-partum sepsis and intra-partum sepsis) and indirect causes were hepatitis $(21.05 \%)$, heart disease $(13.15 \%)$, cerebral malaria $(7.89 \%)$, and anemia $(2.63 \%) .{ }^{7}$ Bedi et al also reported $24 \%$ deaths due to postpartum hemorrhage. ${ }^{14}$ Similar observations were seen in study done by Trivedi et al, where most common indirect cause was hepatitis accounting for $29.43 \%$ of deaths. ${ }^{15}$ Purandare et al observed that among the direct causes, hemorrhage accounts for $70.83 \%$ of deaths; followed by septicemia $(3.3 \%)$ and among the indirect causes, anemia in $55.3 \%$; hepatic disorders in $3.3 \%$ and pulmonary embolism accounting for $6.67 \% .{ }^{16}$ In a study done by Sengupta et al, it was seen that among the direct causes, haemorrhage $(12.40 \%)$ and sepsis $(17.82 \%)$ were the common causes of maternal death and among the indirect causes, hepatitis $(29.93 \%)$ was followed by anaemia $(17.82 \%){ }^{17}$

In the present study, it was observed that 6 deaths took place within 1 hour of admission, followed by 4 deaths within 7-12 hours. Four deaths occured within 25-48 hours and 3 deaths each were within 13-24 hours and 
$>48$ hours. Two deaths occurred within 1-6 hours of admission (Table 3). Purandare et al showed that among the 30 deaths, 3 died within 30 minutes of admission, 14 died between 30 minutes and 6 hours, 7 died between 6 and 24 hours and remaining 6 died after 24 hours of admission. ${ }^{16}$ Sikdar et al reported that $48(19.7 \%)$ died within first 12 hours of admission and another 30 (12.5\%) died within next 12 hours; $78(32.2 \%)$ died within 1 day, $58(23.8 \%)$ died within 1-3 days, 39 (16\%) died in between 4 to 7 days. $^{8}$ Agarwal et al showed that $44 \%$ died within 24 hours of admission and 22\% within 12 hours of hospital stay. ${ }^{9}$ In a study done by Bangal et al, one women died within one hour of admission; 6 (15.79\%) between 2-12 hours of admission; and 8 (21.05\%) between 13-24 hours of admission and 9 (25.06\%) after 7 days of admission. ${ }^{7}$

This shows a delay in referral causes a delay in intervention. This also highlights the importance of adequate and quick transport facilities.

\section{CONCLUSION}

In the present study most, common direct cause of maternal mortality was haemorrhage and anemia was the most common indirect cause. Most maternal deaths were seen in patients from rural areas, unbooked, illiterate patients and patients from low socioeconomic status. Proper health education should be given to the women; early registration of antenatal cases should be done which allows for rapid diagnosis and treatment of high risk cases. Also constructing a well-equipped health care facility with trained staff and prompt transport facilities for early referral can bring down the maternal mortality rate in our country.

\section{ACKNOWLEDGMENTS}

Authors would like to acknowledge Dr. Sujata Sharma, Head of Department, Department of Obstetrics and Gynecology, Government Medical College, Amritsar for the completion of the present task. Authors are also grateful to Dr. Indu Chawla, Senior Specialist, Department of Obstetrics and Gynecology, PGIMER, Dr. R.M.L Hospital for her immense support and help in writing this article.

\section{Funding: No funding sources}

Conflict of interest: None declared

Ethical approval: Not required

\section{REFERENCES}

1. Park K. Preventive medicine in obstetric, Paediatrics and geriatrics: Park's Text Book of Preventive and Social Medicine. 20th edition. Jabalpur: M/S Banarasi Das Bhanot; 2009:479-83.
2. World Health Organization. Maternal mortality in 2000: estimates developed by UNICEF and UNFPA. Geneva: World Health Organization. 2007; 4:16.

3. Mmr_bulletin_2011-13 census (SRS) 2011. Available http://www.censusindia.gov.in/vital_statistics/mmr_b ulletin_2011-13.pdf. [Cited 2015 Nov 22].

4. Mukherjee S, Mukherjee S, Sarkar RR. A six year retrospective study of maternal mortality at a tertiary teaching institute in Uttarpradesh. Int $\mathrm{J}$ Med Sci Public Health. 2014;3(11):1407-9.

5. Kaur D, Kaur A. A retrospective study of maternal mortality in government medical college. J Obstet Gynecol Fam Welfare. 1999;5:18-22.

6. Priti TV. Maternal mortality in Madhya Pradesh. J. Obstetric Gynecol India. 2000;50:59-61.

7. Bangal VB, Giri PA, Garg R. Maternal mortality at a tertiary care teaching hospital of rural India: a retrospective study. Int $\mathrm{J}$ Biol Med Res. 2011;2(4):1043-6.

8. Kamala S, Konar M. Maternal mortality, a 3 year survey in Eden Hospital. J Obstet Gynecol India. 1979;29:76-80.

9. Aggrawal V. Study of maternal mortality. J. Obstet Gynecol India. 1982;32:686-690.

10. Thomas B, Mhaskar A. Review of maternal mortality at tertiary care hospital of India over ten years, Int J Gynecol Obstet India. 2006;9(5):19-21.

11. Pal A, Ray P, Hazra S, Mondal TK. Review of changing trends in maternal mortality in a rural medical college in West Bengal. J Obstet Gynecol India. 2005;55(6):521-4.

12. Verma A, Minhas S, Sood A. A study on Maternal Mortality. J Obstet Gynecol India. 2008;58(3):226-9.

13. Padmanaban P, Raman PS, Mavalankar DV. Innovations and challenges in reducing maternal mortality in Tamil Nadu, India. J Health Population Nutr. 2009 Apr;27(2):202.

14. Bedi N, Kambo I, Dhilion BS. Maternal deaths in India: preventable tragedies. (An ICMR Task Force Study). J Obstet Gynaecol India. 2001;51:86-92.

15. Trivedi SS, Goyal U, Gupta U. A study of Maternal Mortality due to viral hepatitis. J Obstet Gynecol India. 2003;53:551-3.

16. Purandare N, Singh A, Upadhyae S, Saraogi RM. Maternal Mortality at a referral centre: a five year study. J Obstet Gynecol India. 2007;57:248-250.

17. Sengupta A, Gode AG. The study of maternal mortality and morbidity in a North Indian Hospital, A 9 years Review. J Obstet Gynecol India. 1986:394400 .

Cite this article as: Sethi PS, Sharma S, Chawla I. Maternal mortality in a tertiary care centre in North India: a retrospective study. Int J Reprod Contracept Obstet Gynecol 2017;6:5559-62. 